\title{
Performance of paraquat and sethoxydim in arracacha'
}

\author{
María de L. Lugo ${ }^{2}$ and Alvaro Acosta ${ }^{3}$
}

J. Agric. Univ. P.R. 85(1-2):63-68 (2001)

\begin{abstract}
Field experiments were conducted at the Adjuntas Agricultural Experiment Station of the University of Puerto Rico during 1996 and 1998 to evaluate the efficacy of the herbicides paraquat and sethoxydim on arracacha. In 1996, no differences were found among the treatments for weed control four weeks after the first and second herbicide applications. Weed control ranged from $72 \%$ (two applications of sethoxydim) to $87 \%$ (hand weeding) at four weeks after herbicide application, and from $43 \%$ (one application of paraquat) to $97 \%$ (two applications of paraquat) at four weeks after the second herbicide application. There were no significant differences in yield between treatments with two applications of paraquat and that of hand weeding. The lowest yield $(7,632 \mathrm{~kg} / \mathrm{ha})$ was obtained when sethoxydim was applied once. In the 1998 experiment, no differences in weed control were found among treatments at four weeks after the first herbicide application; weed control ranged from $81 \%$ (two applications of sethoxydim) to $98 \%$ (hand weeding). When rated at four weeks after the second herbicide application, the lowest weed control $(84 \%)$ was obtained with one late application of paraquat. There were no significant differences in yield and number of corms per hectare among treatments.
\end{abstract}

Key words: Arracacha, herbicides, weed control, Arracacia xanthorrhiza

\section{RESUMEN}

Desempeño de paraquat y sethoxydim en apio (Arracacia xanthorrhiza)

Se establecieron experimentos de campo con apio en la Estación Experimental Agrícola de Adjuntas de la Universidad de Puerto Rico durante 1996 y 1998 para evaluar la eficacia de los herbicidas sethoxydim y paraquat. En el experimento del 1996, no se encontraron diferencias significativas entre los tratamientos ni a las cuatro semanas después de la primera aplicación de herbicida ni cuatro semanas después de la segunda aplicación de herbicida. El control de malezas fluctuó desde $72 \%$ (dos aplicaciones de sethoxydim) hasta $87 \%$ (desyerbo manual) a las cuatro semanas después de la primera aplicación de los herbicidas, y desde $43 \%$ (una aplicación de paraquat) hasta $97 \%$ (dos aplicaciones de paraquat) a las cuatro semanas después de la segunda aplicación de herbicidas. No se obtuvieron diferencias significativas en rendimiento entre las aplicaciones de paraquat y el desyerbo a mano. En el experimento del 1998, no se encontraron diferencias significativas en el control de malezas entre los tratamientos que se aplicaron cuatro semanas después de la primera aplicación de los herbicidas. El

${ }^{1}$ Manuscript submitted to Editorial Board 9 October 2000.

${ }^{2}$ Associate Weed Scientist, Department of Crop Protection, University of Puerto Rico, Mayagüez Campus, P.O. Box 1306, Gurabo, P.R. 00778.

${ }^{3}$ Research Assistant, Department of Horticulture. 
control de las malezas fluctuó entre $81 \%$ (dos aplicaciones de sethoxydim) hasta $98 \%$ (desyerbo manual). Cuando se evaluó a las cuatro semanas después de la segunda aplicación de los herbicidas, el control más bajo $(84 \%)$ se obtuvo con una aplicación tardía de paraquat. Al igual que en 1996 no se obtuvieron diferencias significativas en rendimiento.

\section{INTRODUCTION}

In Puerto Rico, arracacha (Arracacia xanthorrhiza) is grown as a specialty tuber. Production during $1997-98$ was estimated at $318,810 \mathrm{~kg}$ for a farm value of $\$ 274,000$ (Dept. of Agric., 1998). In many field situations weeds begin to interfere with this crop early in the cycle. Propagation material of arracacha deteriorates rapidly. Because its production is under rain-fed conditions, a low stand is likely if a drought period occurs after planting. The above situation increases the chances for weed interference (Ortiz et al., 2000). Arracacha itself is considered a poor competitor against weeds (Lugo and Acosta, 1999). Season-long weed interference reduces yield dramatically (Del Valle-González et al., 1990; Liu et al., 1997; Olivieri and Beale, 1984). Because the crop is usually grown on hilly land, mechanical weed control methods are of limited application; thus, hand hoeing is the only practical weed control method that can be applied in commercial plantations. These studies recognized weed interference as a major limitation in the management in arracacha, for which there is a lack of registered herbicides, as is the case for other root and tuber crops grown in Puerto Rico.

Efforts to register herbicides for their use in this crop in Puerto Rico have been unsuccessful. Ametryn efficacy in arracacha was established by Del Valle et al. (1990). However, the ametryn manufacturer did not support the registration.

Studies with oxyfluorfen demostrated that it caused severe crop phytotoxicity even with 95\% weed control (Olivieri and Beale, 1984). Liu et al. (1997) found clomazone a potential herbicide for arracacha although it caused temporary phytotoxicity. In that study clomazone at rates of 1.68 and $3.36 \mathrm{~kg}$ ai/ha controlled 83 and $95 \%$ of broadleaves, respectively, and $90 \%$ or more of grasses. Clomazone registration has not been completed. With the scenario of intensive labor, high cost for weed control, and the lack of registered herbicides, efforts toward finding practical weed control alternatives are imperative. The objective of this study was to evaluate the efficacy and phytotoxicity of sethoxydim and paraquat to obtain the baseline information for registration and use in a new weed control strategy in arracacha.

\section{MATERIALS AND METHODS}

Two field experiments were conducted at the Adjuntas Agricultural Experiment Station of the University of Puerto Rico during 1996 and 
1998. This location is $549 \mathrm{~m}$ above sea level. The first experiment was established 19 April 1996 on a Mollisols of the Toa series (Fluventic Hapludolls) with a pH of 6.05 and $1.44 \%$ organic matter. Setts of cv Criolla were planted $30 \mathrm{~cm}$ apart in double rows within a $1.3-\mathrm{m}$ wide bed; beds were $0.60 \mathrm{~m}$ apart. Each plant was side dressed with $28 \mathrm{~g}$ of 10-10-10 (N$\mathrm{P}-\mathrm{K}$ ) fertilizer applied two months after planting, and the same rate was repeated three months later. Sprinkler irrigation was applied as needed.

Five weed control treatments were evaluated: 1) hand weeded check, 2) one directed application of paraquat at $0.56 \mathrm{~kg} \mathrm{ai} / \mathrm{ha} ; 3)$ two directed applications of paraquat at $0.56 \mathrm{~kg}$ ai/ha; 4) one application of sethoxydim at $0.34 \mathrm{~kg} \mathrm{ai} / \mathrm{ha}$; and 5) two applications of sethoxydim at $0.34 \mathrm{~kg}$ ai/ha. A randomized complete block design with four replications was used. The first herbicide applications were made seven weeks after planting (WAP) and the second 12 WAP. Visual rating for weed control and phytotoxicity was recorded four weeks after each herbicide application. Weed density and phytotoxicity were recorded four weeks after the first herbicide application. Hand hoeing was done after the evaluation of the herbicide treatments. Harvest was 42 WAP.

A second experiment was established 21 December 1998 and was conducted on an Ultisols of the Alonso series (Typic Haplohumults). The soil had a pH of 4.8 and $2.52 \%$ organic matter. For this experiment, setts were planted $30 \mathrm{~cm}$ apart in a single row. Rows were $90 \mathrm{~cm}$ apart. This experiment included the treatments evaluated in 1996 and an additional treatment consisting of one application of paraquat at $0.56 \mathrm{~kg}$ ai/ha 8 WAP. The first herbicide application was made 4 WAP and the second 12 WAP. Field management and data collection was the same as for the 1996 experiment. Harvest was 39 WAP. The experiments were statistically analyzed separately.

\section{RESULTS AND DISCUSSION}

In the 1996 experiment, predominant weeds were Virginia pepperweed (Lepidium virginicum L.), galinsoga (Galinsoga spp.), marygrass [Setaria barbata (Lam.) Kunth], goosegrass [Eleusine indica (L.) Gaertn.], and purple nutsedge (Cyperus rotundus L.). No differences were found among treatments for weed control rating when recorded at four weeks after the first and second herbicide applications (Table 1). Weed control ranged from $72 \%$ (two applications of sethoxydim) to $87 \%$ (hand weeding) at four weeks after herbicide application. At four weeks after the second herbicide application weed control ranged from $43 \%$ (one application of paraquat) to $97 \%$ (two applications of paraquat). High broadleaf densities of 73 and 83 plants per square meter in the sethoxydim treatments were associated with the selectivity of this herbicide. Paraquat applied twice was the only treatment found to cause crop phy- 
TABLE 1.-Evaluation of paraquat and sethoxydim for weed control, weed density and yield component during 1996.

\begin{tabular}{|c|c|c|c|c|c|c|c|}
\hline \multirow[b]{2}{*}{ Herbicide treatments } & \multirow[b]{2}{*}{ Rate } & \multicolumn{2}{|c|}{ Weed control } & \multicolumn{2}{|c|}{ Weed density" } & \multirow[b]{2}{*}{ Yield } & \multirow{2}{*}{$\begin{array}{c}\text { Yield } \\
\text { component }\end{array}$} \\
\hline & & 4 WAHA $^{1}$ & $4 \mathrm{WA}_{2} \mathrm{HA}^{2}$ & Grasses & Broadleaves & & \\
\hline & $\mathrm{kg}$ ai/ha & \multicolumn{2}{|c|}{$\ldots \ldots \ldots-\ldots-\ldots \ldots . .}$. & \multicolumn{2}{|c|}{ plants $/ \mathrm{m}^{2}$} & $\mathrm{~kg} / \mathrm{ha}$ & corms/ha \\
\hline One application of paraquat & 0.56 & 83 & 43 & 27 & 24 & 13,569 & 15,672 \\
\hline Two applications of paraquat & 0.56 & 84 & 97 & 10 & 11 & 16,452 & 12,873 \\
\hline One application of sethoxydim & 0.34 & 85 & 77 & 15 & 83 & 7,632 & 16,231 \\
\hline Two applications of sethoxydim & 0.34 & 72 & 67 & 50 & 73 & 10,855 & 16,231 \\
\hline Hand weeding & - & 87 & 65 & 44 & 8 & 16,282 & 16,418 \\
\hline $\operatorname{LSD}(<0.05)$ & & NS & NS & NS & 22 & 2,829 & NS \\
\hline
\end{tabular}

${ }^{1} 4 \mathrm{WAHA}=$ four weeks after first herbicide application.

${ }^{2} 4 \mathrm{WA} 2 \mathrm{HA}=$ four weeks after second herbicide application.

${ }^{3}$ Weed density was determined four weeks after first herbicide application. 
TABLE 2.-Evaluation of paraquat and sethoxydim for weed control and yield component during 1999.

\begin{tabular}{|c|c|c|c|c|c|c|c|}
\hline \multirow[b]{2}{*}{ Herbicide treatments } & \multirow[b]{2}{*}{ Rate } & \multicolumn{2}{|c|}{ Weed control } & \multicolumn{2}{|c|}{ Weed density ${ }^{3}$} & \multirow[b]{2}{*}{ Yield } & \multirow{2}{*}{$\begin{array}{c}\text { Yield } \\
\text { component }\end{array}$} \\
\hline & & $4 \mathrm{WAHA}^{1}$ & $4 \mathrm{WA}_{2} \mathrm{HA}^{2}$ & Grasses & Broadleaves & & \\
\hline & $\mathrm{kg}$ ai/ha & \multicolumn{2}{|c|}{$\ldots \ldots \ldots \ldots \ldots$} & \multicolumn{2}{|c|}{ plants $/ \mathrm{m}^{2}$} & $\mathrm{~kg} / \mathrm{ha}$ & corms/ha \\
\hline One late application of paraquat & 0.56 & - & 84 & - & - & 16,595 & 15,548 \\
\hline Two applications of paraquat & 0.56 & 95 & 100 & 4 & 10 & 17,342 & 14,352 \\
\hline One application of sethoxydim & 0.34 & 92 & 90 & 13 & 75 & 18,389 & 15,249 \\
\hline Two applications of sethoxydim & 0.34 & 81 & 94 & 27 & 73 & 14,352 & 15,249 \\
\hline Hand weeding & - & 98 & 100 & 0 & 4 & 17,791 & 15,847 \\
\hline $\operatorname{LSD}(<0.05)$ & & NS & 10 & 12 & 31 & NS & NS \\
\hline
\end{tabular}

${ }^{14} \mathrm{WAHA}=$ four weeks after the first herbicide application.

${ }^{2} 4 \mathrm{WA} 2 \mathrm{HA}=$ four weeks after the second herbicide application.

${ }^{3}$ Weed density was determined four weeks after first herbicide application. 
totoxicity (20\%) (data not shown). However, plants overcame paraquat injury, and yield was not significantly different from that with hand weeding. There were no significant differences in yield among two applications of paraquat and hand weeding (Table 1). There were differences in yield among one or two applications of sethoxydim and hand weeding. The lowest yield $(7,632 \mathrm{~kg} / \mathrm{ha})$ was obtained when sethoxydim was applied once. No significant differences were observed among treatments for the number of corms per hectare (Table 1). Since this yield component was not affected, the significant reduction of corm fresh weight was a result of early weed interference. The predominant weeds in the second experiment were galinsoga, Virginia pepperweed, lion's ear [Leonotis nepetifolia (L.) R.Br. In Ait. f.], morning glory (Ipomoea spp.), spreading dayflower (Commelina diffusa Burm. f.), goosegrass, and junglerice (Echinochloa colona L.). No significant differences in weed control were found among treatments at four weeks after the first herbicide application; weed control ranged from $81 \%$ (two applications of sethoxydim) to $98 \%$ (hand weeding) (Table 2). When rated at four weeks after the second herbicide application, the lowest weed control $(84 \%)$ was obtained with one late application of paraquat. As expected, broadleaf density was high in the sethoxydim treatments (Table 2). There were no significant differences in yield and number of corms per hectare among treatments. Arracacha growers need weed control alternatives for their crops. Paraquat is a chemical alternative that gave relatively satisfactory weed control; yield was similar to that produced with hand weeding. Sethoxydim is a good alternative where grasses are predominant in the arracacha fields. These studies gave some baseline information about the efficacy and phytotoxicity of these two herbicides in arracacha production. Both can be acceptable alternatives for this crop since hand weeding is expensive.

\section{LITERATURE CITED}

Del Valle-González, R., M. Santiago-Córdova and A. González, 1990. Efecto del yerbicida ametrina como control preemergente de yerbajos en apio (Arracacia xanthorrhiza Bancroft). J. Agric. Univ. P.R. 74(3):273-280.

Departmento de Agricultura de PR, 1998. Ingreso bruto y neto de la agricultura de Puerto Rico 1997-98. Oficina de Estadísticas Agrícolas, Departamento de Agricultura, Santurce, P.R.

Liu, L. C., E. Orengo-Santiago and M. de L. Lugo, 1997. Evaluation of clomazone in arracacha and cassava. J.Agric. Univ. P.R. 81(3-4):223-225.

Lugo, M. de L, and A. Acosta, 2000. Weed interference in arracacha. Proc. Caribbean Food Crops Soc. 35:232-235.

Olivieri-Cintrón, L. J. and A. Beale, 1984. Evaluación de yerbicidas en Arracacia xanthorrhiza Bancroft. Proc. Caribbean Food Crops Soc. 19:141-145.

Ortiz, C. E., E. Orengo-Santiago and A. Acosta, 2000. Influence of sett fresh weight and depth of planting on the performance of arracacha. J. Agric. Univ. P.R. 84(3-4):143-151. 